\title{
STORING AN OVERSIZED MUSEU DE LISBOA TEXTILE BANNER COLLECTION
}

\author{
Aida Pereira Nunes ${ }^{1}$ \\ ${ }^{1}$ EGEAC-Museu de Lisboa, Palácio Pimenta, Campo Grande 245, 1700-097 Lisboa, Portugal - aidanunes@egeac.pt
}

KEY WORDS: Textile banners, Oversize, Backing panel, Tycore board, Framing, Storing vertically

\begin{abstract}
:
In 1947 Lisbon held the "Cortejo Histórico de Lisboa", a parade belonging to the "VII Centenary of the Reconquest of Lisbon to the Moors" celebrations. For the accomplishment of this parade, hundreds of scenic objects and accessories were created and three thousand extras and actors participated. Museu de Lisboa has in its collection a significant set of these objects, with highlight to the seventeenbanner collection. These banners that since 1947 were kept in different warehouses, were transferred in 2008 to the Museu de Lisboa Central Storage Unit textile room. The large dimensions of these objects were the main preventive conservation issue the Museum had to solve, regarding the way of storing the collection. In 2018 the Museum designed a project for the vertical storage of these banners. Due to its enormous size (being the biggest $315 \mathrm{~cm}$ height and $212 \mathrm{~cm}$ width) it was impossible for the museum to store these objects in flat format. The alternative was designed and executed using Tycore ${ }^{\circledR}$ boards as backing panel, hinged with acid-free buffered paper sheets and then glued together into one large piece with the same size as each banner. The banners with textile strip extensions were mounted onto the panels and stored vertically on metallic grids used for the storage of the Museum painting art collection. Treatments such as dust cleaning, tear consolidation and stain removal were carried out to stabilize the banners prior to the mounting on the boards. This paper describes some of the steps of this eight-month project, involving six people.
\end{abstract}

\section{INTRODUCTION}

Museu de Lisboa has a heritage collection, with about 61,000 objects, classified in several categories: painting, graphic documents, furniture, ceramics, metals, sculpture, etc.

In the textile category, the "Cortejo Histórico de Lisboa" (Lisboa Historic Parade) collection is the biggest and most numerous. This Parade, belonging to the "VII Centenary of the Reconquest of Lisbon to the Moors" celebrations took place on July 6, 1947 and was organized by Leitão de Barros (1947a; 1947b).

This parade, inspired by the magnificent ceremonies of the Portuguese king Manuel I, had the collaboration of more than three thousand extras, dressed according to the costumes of the time, numerous scenic cars, sidewalks, trays and a whole set of accessories necessary for the reconstitution of the life time of this monarch. One of the purposes of this parade was to recreate the civil and religious organization and the popular and erudite activities of the Lisbon residents, through the experiences and traditions of its craftsmen.

The following photographs (figure 1), belonging to the Arquivo Municipal de Lisboa - Fotografia (Arquivo Municipal de Lisboa), were made by the photographer Judah Benoliel (18901968) and depict some moments of this parade ${ }^{i}$
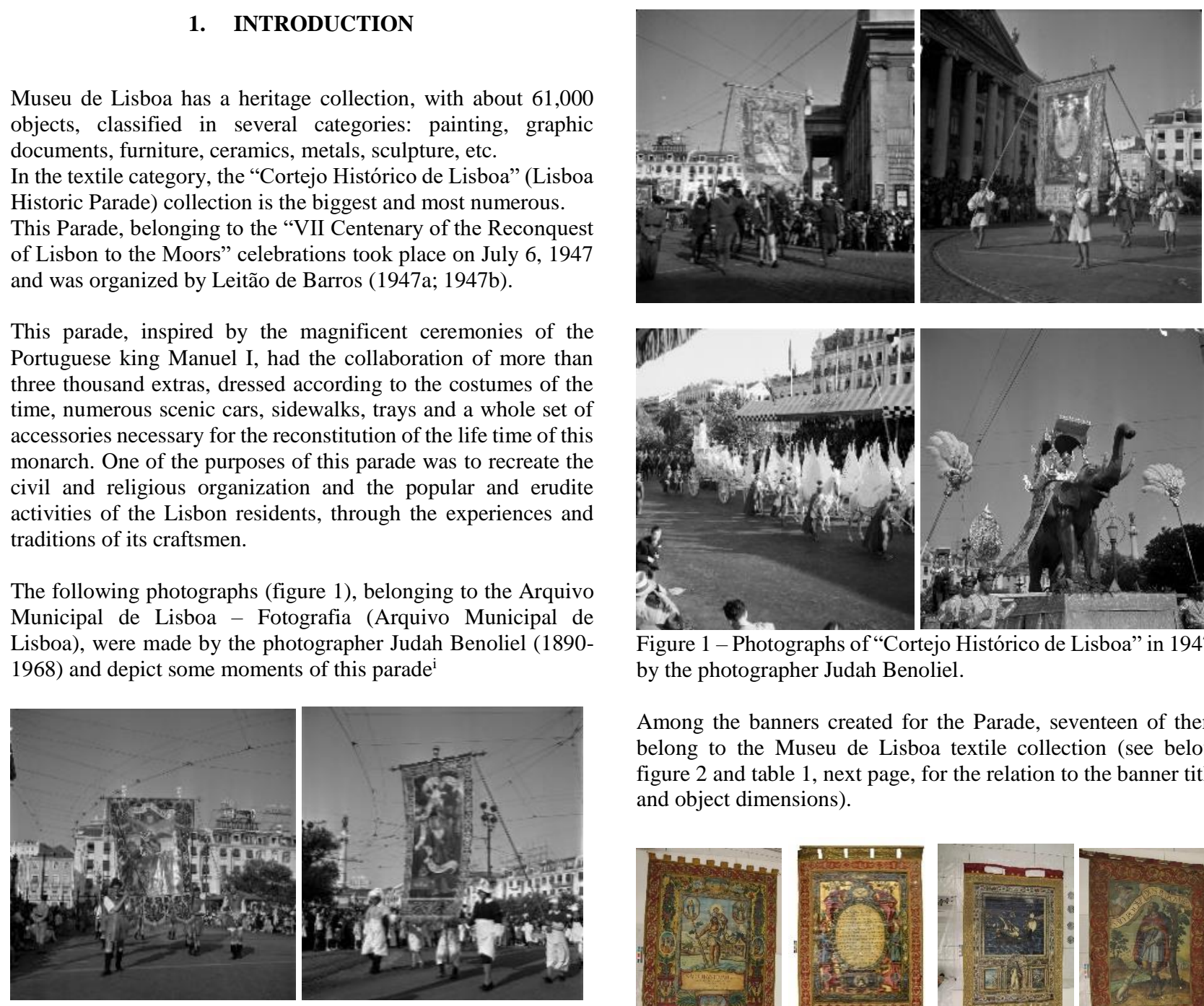

Figure 1 - Photographs of "Cortejo Histórico de Lisboa" in 1947 by the photographer Judah Benoliel.

Among the banners created for the Parade, seventeen of them belong to the Museu de Lisboa textile collection (see below figure 2 and table 1 , next page, for the relation to the banner title and object dimensions).

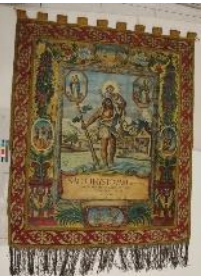

S. Cristóvão

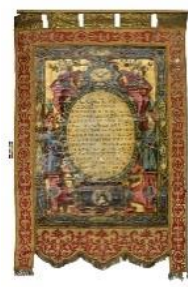

Pescadores

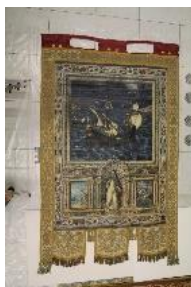

S. Vicente

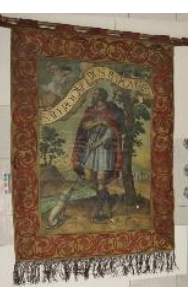

S. Roque 


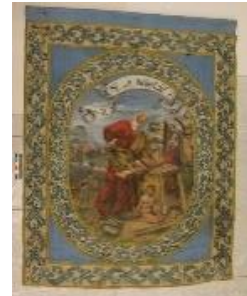

S. José

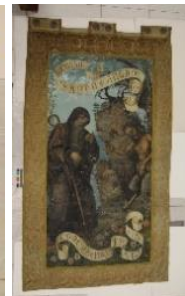

S. Antão

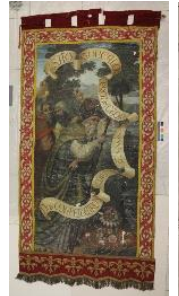

S. Gonçalo

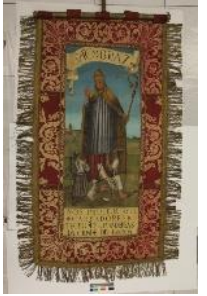

S. Brás

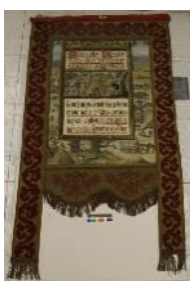

Terreiro Trigo

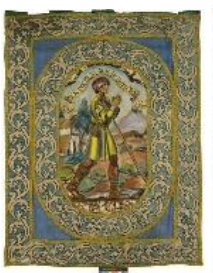

S. Paulino

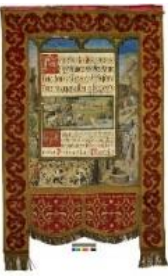

Sintra

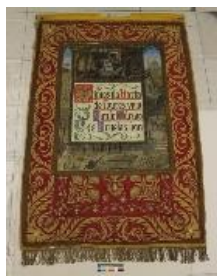

S. Adrião

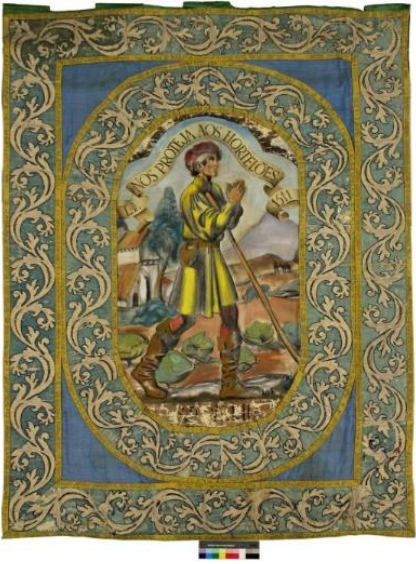

Figure 3 - (S. Paulino banner)

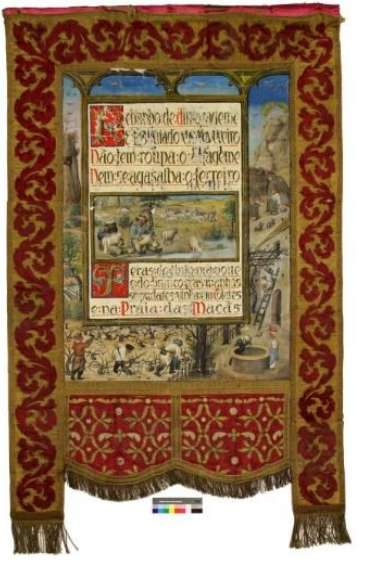

Figure 4 - (Sintra banner)
The subject of the central motif is related to the patron saint of the professions present in the parade (fishermen, carpenters, masons, tailors, shoemakers, goldsmiths, potters, etc.) or with paintings and ilustrations of "Livro de Horas de D. Manuel I" a book that illustrates several agricultural activities.

This banner collection was stored for decades in deposits in very adverse environmental conditions and in 2008 was transferred to the Museu de Lisboa Central Storage Unit textile room. Due to the large formats of these objects and their poor condition, they remained overlapped, on a wooden cabinet, and the set was protected with a plastic cover to prevent from dust deposition (figure 5).

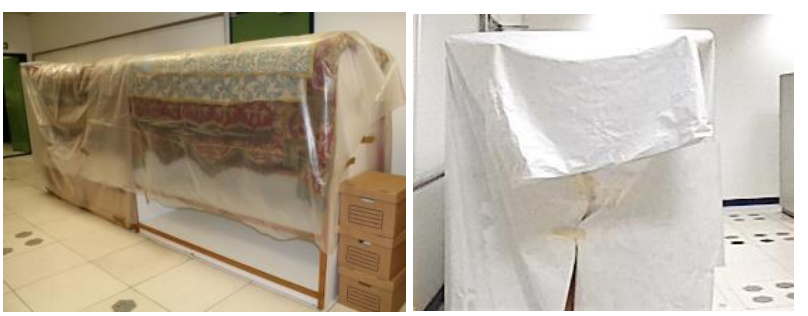

Figure 5 - Storage solution adopted for the seventeen-banner collection, between 2008 and 2018 .

This storage solution made it impossible for individual access to objects, for study, photographic documentation, inventory or conservation and restoration treatments. On the other hand, the overlap caused superficial damage and frictional lacerations on the central motif printed paper (Figure 6) or tears on different fabric elements composing each banner (Figure 7), when it was necessary to access objects in lower layers, due to the large formats in presence. Clearly this collection was in a bad storage condition that gave rise to preventive conservation issues and object damages.
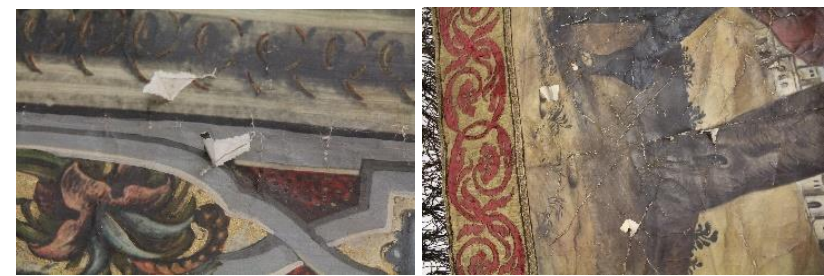

Figure 6 - Examples of superficial laceration on banners $\mathrm{S}$. Vincent (left) and S. Roque (right)

The central motif is inserted in a textile border with stylized vegetal motifs, surrounded by a bevelled border with or without a metal strip (figure 3), that in some objects, form two pendants and termination with cutworks (figure 4).

The upper edge has a fabric strip with openings for placing the suspension rod. The lower edge is usually finished with metal strip. 

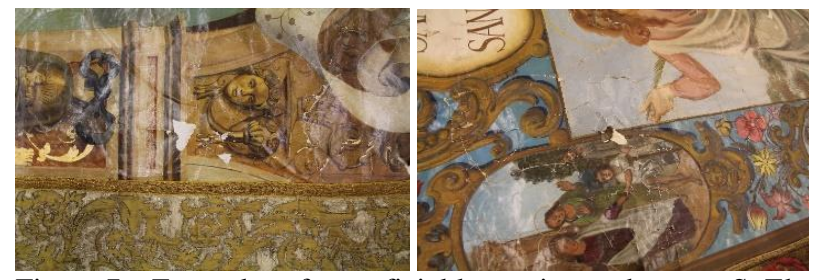

Figure 7 - Examples of superficial laceration on banners S. Eloy (left) and Sta Justa (right)
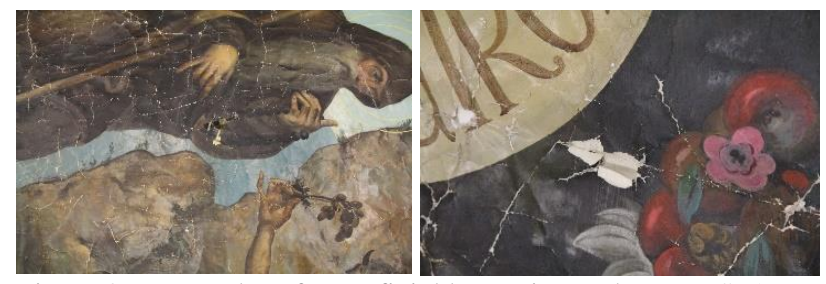

Figure 8 - Examples of superficial laceration on banners S. Antão (left) and S. Gonçalo (right)

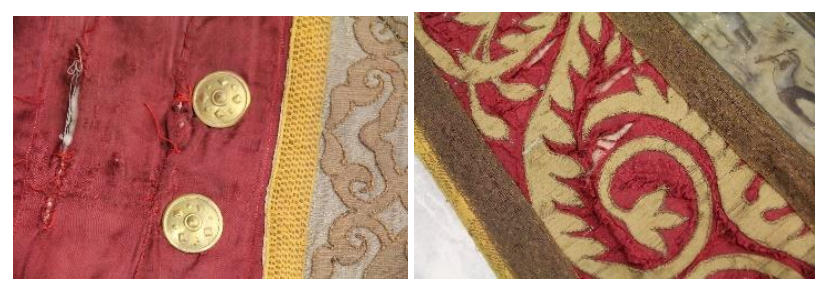

Figure 9 - Examples of tears on fabric elements on banners $\mathrm{S}$. Vincent (left) and S. Adrião (right)
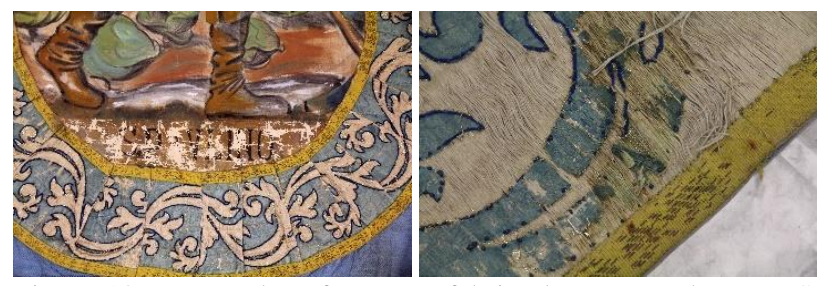

Figure 10 - Examples of tears on fabric elements on banners $\mathrm{S}$ Paulino (left) and S. José (right)

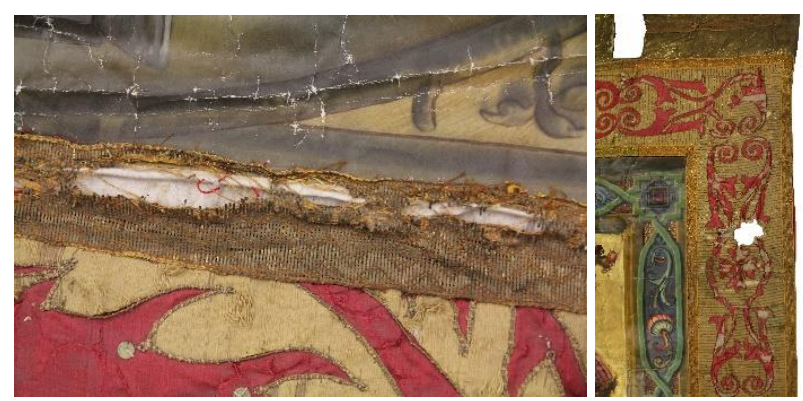

Figure 11 - Examples of tears on fabric elements on banners S. Adrião (left) and Pescadores (right)

\section{THE STORAGE PROJECT FOR THE BANNER COLLECTION}

In January 2018, several possibilities to correct this preventive conservation issue were studied by Museu de Lisboa. The obvious limitation was the size of the banners. If they could be stored horizontally, the structure to receive them would be too big and cause many space issues in the textile room. Store the collection vertically, in metallic grids in the painting room, where the grids were large enough to accommodate the banners $(2,70 \mathrm{~m} \times 3,00 \mathrm{~m})$, seemed to us as the best solution. However, the fragility of the textile materials and their excessive weight discouraged direct suspension. It would be necessary to mount each banner onto a rigid structure with the same size and only then fix it to the metal grid.

Tycore ${ }^{\circledR}$ boards seemed to be as the best available product in the market to be used as a back support for the collection because it is a very light material, stable and inert. Tycore ${ }^{\circledR}$ boards are made with two-sided paperboard planks, made of highly refined cellulose, free of acid and lignin, with alkaline reserve, with a honeycomb interior and thickness of $6,5 \mathrm{~mm}$.

In the literature on solutions for conditioning works of art (Tsai, F. W., 2009), this Tycore ${ }^{\circledR}$ panels were used as a rigid support for large format drawings (charcoal on paper), which were later placed on metal grids, a solution very similar to the one we wanted to use.

Moving forward with the project, a model was created to test the initial design hypothesis (Figure 12 and 13). Each banner should receive textile strips extensions on three sides (upper side and laterals). The panels should be shaped with the same dimension of the banners and receive Velcro strips on three sides, close to the edge. The banners with the textile extensions should be mounted onto the panels.

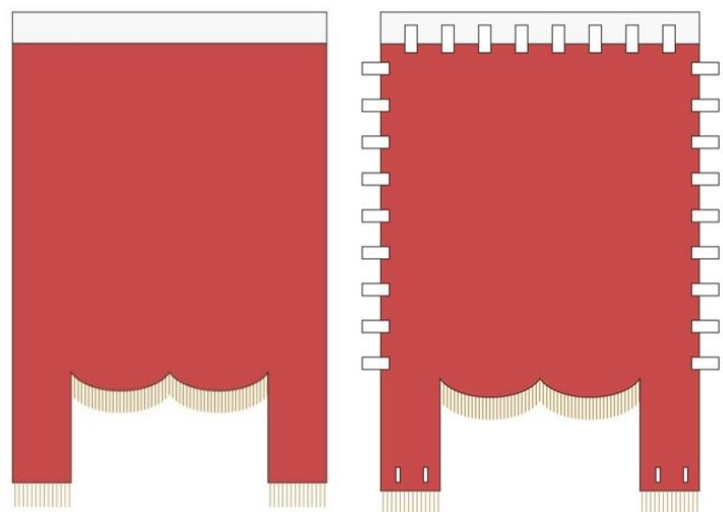

Figure 12 - Back of the banner (left) and banner with textile strip extensions on there sides (right)
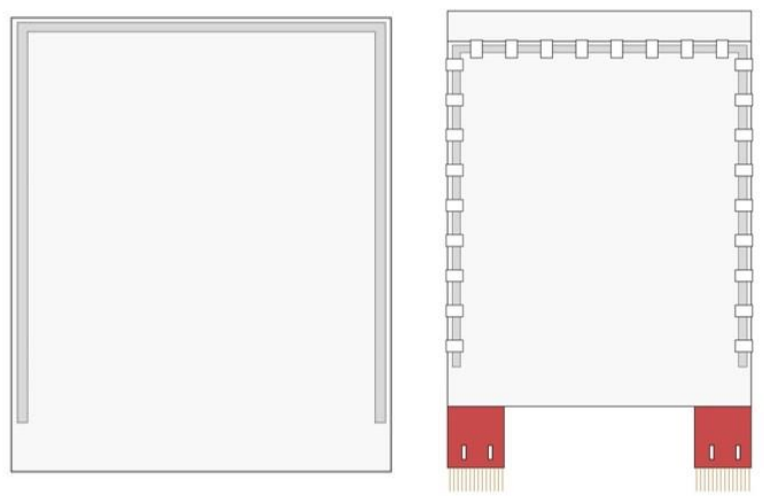

Figure 13 - Panel with Velcro strips (left) and banner and panel mounted together (right)

The model seemed to be a very stable way to store these textile objects, so we applied the methodology to the objects.

The first step was to decide which position for each banner since the height of some exceeded the height of the grid $(2,70 \mathrm{~m})$ and so, had to be placed horizontally. 
With this definition completed, the textile strips extensions were sewn on three sides of the back of each banner. The textile strips extensions were squared shape, measuring $15 \mathrm{~cm}$ side, were placed every $15 \mathrm{~cm}$ and had a Velcro strip on the top of the side faced to the back of the banner.

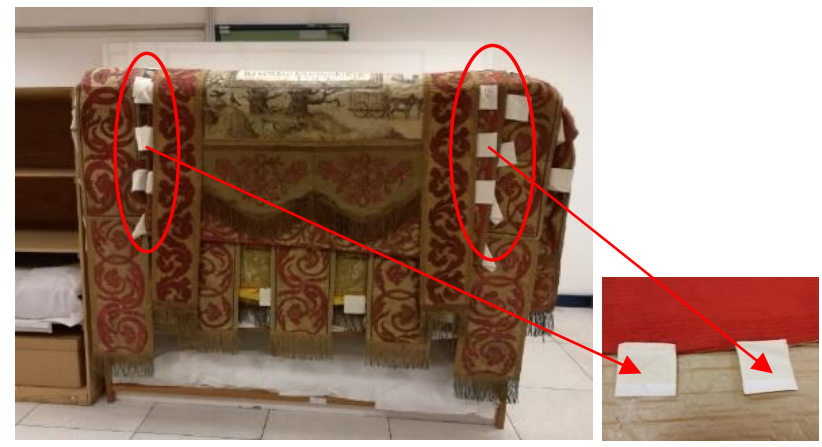

Figure 14 (left) - Banners with the textile strips extensions. And textile strips extensions, squared shape, with Velcro strip on the top of the side faced to the back of the banner (right).

In some banners the pendants and fringes also exceeded the height of the grids. In these cases and following the original model (Figure 15) besides sewing the textile strip extensions we also applied textile loops on the back of the pendants, to be folded and fixed directly to the metal grilles with a textile tape (Figure 16).
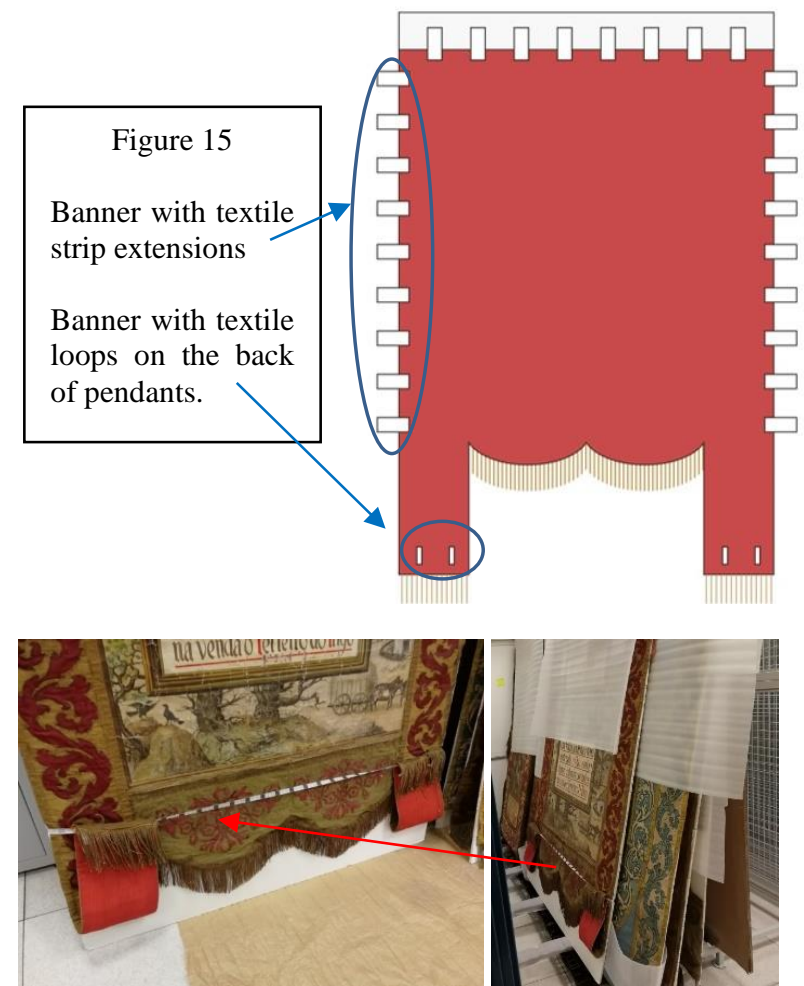

Figure 16 - The designed solution to suspend the pendants too long for the height of the grids and to fix them with textile ribbons.

When we finished the process of textile strip extensions and loops on the back of the pendants, a minimal conservation treatment was carried out to stabilize the banners, including dust surface cleaning, tear consolidation (Figure 17) and stain removal.
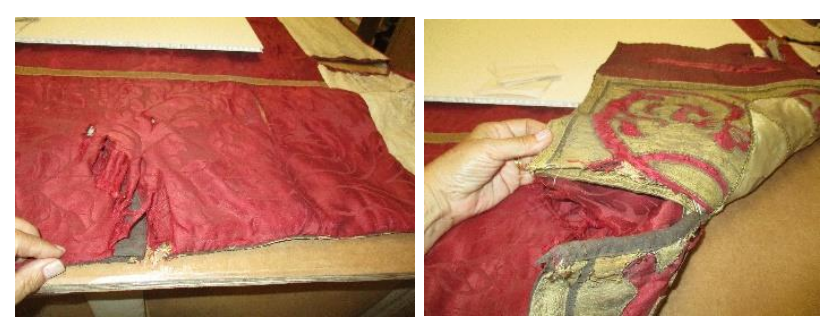

Figure 17 - Tear consolidation on Sta Justa banner.

We then started to work with the panels. Tycore ${ }^{\circledR}$ boards were dimensioned for each banner. In some cases, we had to remove small sections from the original board size, but in general we had to glue sections cuted to size. Large acid-free buffered paper strips, (Perma/Dur®Bond) were used, glued perpendicular to the joint with Evacon R (water-soluble, non-plasticized ethylenevinyl acetate copolymer emulsion) and reinforced with another perpendicular strip applied on the previous ones and with the same length of the joint. This procedure was applied on both sides of the board (Figure 18).

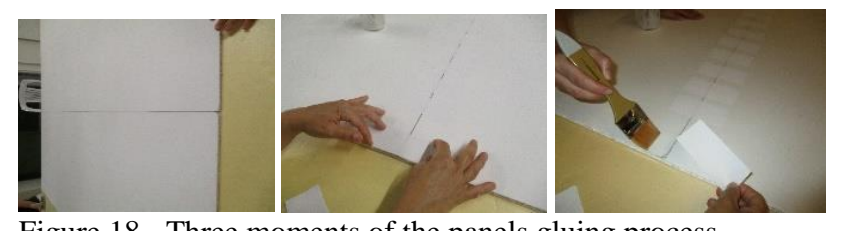

Figure 18 - Three moments of the panels gluing process.

Then each banner was placed horizontally, with the back side up and placed on top the corresponding Tycore ${ }^{\circledR}$ board. The banner textile strip extensions were folded toward the board to define the board Velcro strips position (Figure 19).
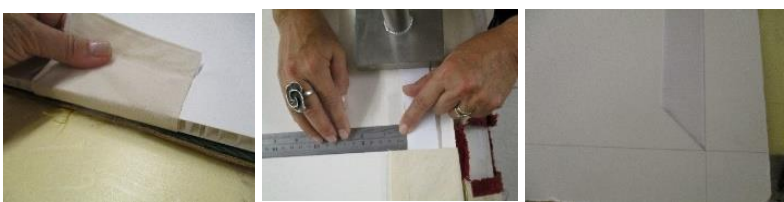

Figure 19 - Three moments of applying the Velcro strips on the back of the panels.

The banners were mounted onto the panels, by simply adjusting the banners textile strip extensions with the Velcro on the back of the boards, without creating tensions that could endanger the fabrics. With this procedure, the weight of the banner was equally divided by all the extensions, ensuring a correct distribution of the physical forces caused by the weight (Figure 20).
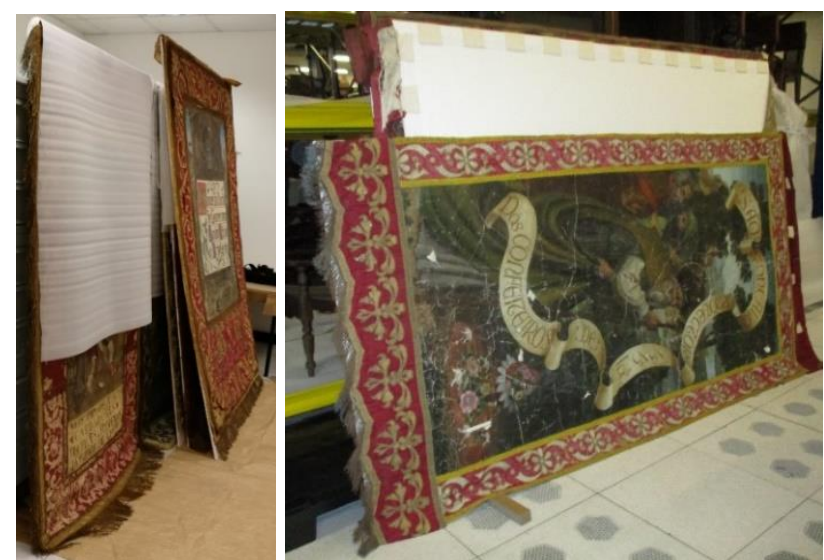

Figure 20 - Some of the banners mounted onto the rigid Tycore ${ }^{\circledR}$ boards, ready to be fixed to the metallic grids. 
When we placed the banners vertically, it was clear that the initial hypothesis was satisfactory validated and that each object was now physically stable and could be fixed to the grids with metal hooks (Figure 21).

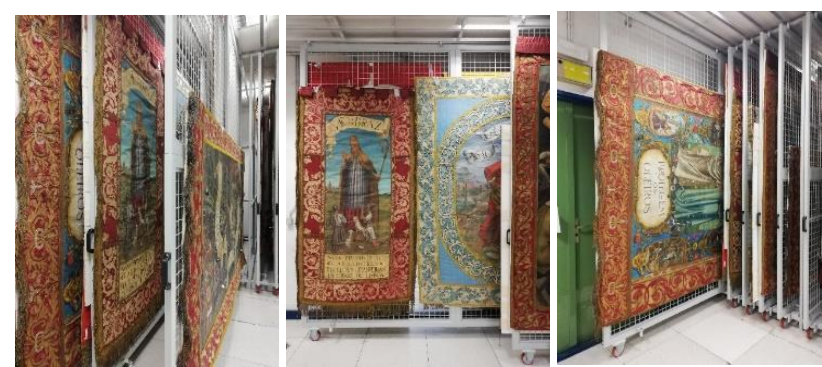

Figure 21 - An overview of some grids with banners fixed.

Flat hooks were placed on the lower edge of the Tycore ${ }^{\circledR}$ boards, fixing it to the grid and supporting the weight of the set and rounded hooks were placed on the upper edge, simply to adjust the set to the grid, protected with a protective cell-air strip interlayer between the hook and the object (Figure 22).
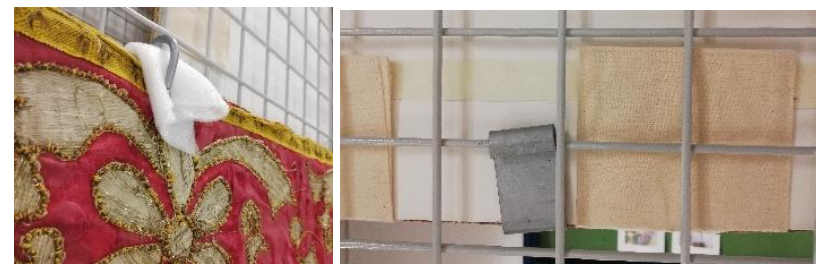

Figure 22 - Examples of round (left) and flat hoops (right).

Textile ribbons were used to suspend long pendants, passing them through the loops and attaching to the grids (Figure 23).
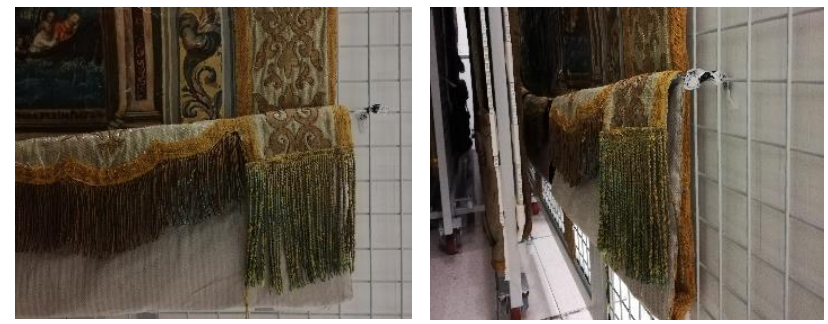

Figure 23 - Suspension of long pendants with textile ribbons.

\section{CONCLUSIONS}

A set of seventeen banners, designed in 1947 for the "Cortejo Histórico de Lisboa", which are part of the textile collection of the Lisbon Museum, presented, for decades, a storage and a conservation issue, due to the oversized dimensions of the objects.

This collection was stored for decades in deposits in very adverse environmental conditions and was transferred in 2008 to the textile room of Museu de Lisboa Main Storage Unit. There the seventeen banners remained overlapped on a wooden cabinet, since there was no other more suitable solution to store this collection.

At the beginning of 2018 a preventive conservation project was designed for the correct storage of this collection, placing it vertically, using existing metal grides in the paint room, large enough to accommodate the banners $(2,70 \mathrm{mx} 3,00 \mathrm{~m})$.

Tycore ${ }^{\circledR}$ boards were used as rigid backing panels, they were shaped and glued to fit the size of each banner and Velcro strips were added at the back, close to three edges.

Banners had textile strip extensions, stitched on the back, on three sides and loops on the pendants, too long to fit the height of the grids.

A minimal conservation treatment was carried out on the banners, involving dust surface cleaning, tear consolidation and stain removal.

The banners were mounted on the panels and fixed on the extractive metallic grids, with hooks.

With this solution every object is accessible, stable, can be studied and preventive conservation treatments can be done individually.

This storage project and at the same time a big scale preventive conservation procedure, applied to this collection, carried out by a team of six people, for eight months, which began with a timid hypothesis, was validated and proved to be a very successful one. The same project will be applied in 2019 to another ten-silk banner collection, belonging to Museu de Lisboa and dedicated to Saint Antony, the Lisbon patron. This collection has similar dimensions and the present storage solution is the same as described previously so it clearly needs an urgent correction of this storage issue.

\section{REFERENCES}

Arquivo Municipal de Lisboa - Fotografia, [Comemorações do VIII Centenário da Tomada de Lisboa aos Mouros - O Cortejo Histórico]

http://arquivomunicipal2.cm-

lisboa.pt/sala/online/ui/searchbasic. aspx?filter=AH;AI;AC;AF

Tsai, F. W., 2009. Using Tycore Board as Mounting Panel for Oversized Charcoal Drawing In: The Book and Paper Group Annual, Vol 28, 73

https://cool.conservationus.org/coolaic/sg/bpg/annual/v28/bp28-15.pdf

1947a. O Grande Cortejo Histórico de Lisboa, Sociedade Astória Limitada, Lisboa.

1947b. Ano Comemorativo do VIII Centenário da Tomada de Lisboa aos Mouros, Revista Municipal n 33, Câmara Municipal de Lisboa, Lisboa.

\footnotetext{
${ }^{\mathrm{i}}$ Dimensions of the photos: $6 \times 6 \mathrm{~cm}$. Materials: gelatin and
} silver on cellulose acetate 